\title{
Roles and Hopes of Family Members Living with SMID Children in Japan
}

\author{
Rie Wakimizu1 ${ }^{*}$, Keiko Yamaguchi², Hiroshi Fujioka ${ }^{3}$ \\ ${ }^{1}$ Department of Child Health Care Nursing, Division of Health Innovation and Nursing, Faculty of Medicine, \\ University of Tsukuba, Tsukuba City, Japan \\ ${ }^{2}$ Department of Nursing Science, Graduate school of Comprehensive Human Sciences, University of Tsukuba, \\ Tsukuba City, Japan \\ ${ }^{3}$ Department of Nursing, Faculty of Health Sciences, Tsukuba International University, Tsuchiura City, Japan \\ Email: *riewaki@md.tsukuba.ac.jp, s1421355@u.tsukuba.ac.jp,h-fujioka@tius.ac.jp
}

Received 1 February 2016; accepted 4 June 2016; published 8 June 2016

Copyright (C) 2016 by authors and Scientific Research Publishing Inc.

This work is licensed under the Creative Commons Attribution International License (CC BY).

http://creativecommons.org/licenses/by/4.0/

(c) (†) Open Access

\begin{abstract}
The number of children with Severe Motor and Intellectual Disabilities (SMID) receiving medical treatment/recovering at home is rising yearly. Although benefits of this care are emphasized, the stress and duties of family members in the household are extremely great, especially because Japan is becoming a society of nuclear families. In this study, we described the lifestyles of nuclear families providing in-home medical care for children with SMID, focusing on family members' roles. Roles of mothers, fathers, and siblings of children with SMID were summarized from semistructured interviews. As a result, for "the roles of each family member living with a child with SMID", mothers had five roles, fathers seven, and siblings five. For "the hopes of each family member living with a child with SMID", parents desired the whole family collaboration in care for children with SMID, and as caregivers, parents' common thoughts included wanting siblings in order to help care for the child with SMID and wanting siblings to treasure their own lives. Siblings wanted their mother to have some time for rest and expected their fathers to have two main roles. They also expected their grandparents and other siblings to fulfill roles.
\end{abstract}

\section{Keywords}

Children with Severe Motor and Intellectual Disabilities (SMID), Family Life, Interfamilial Roles, Family Empowerment, Japan

\section{Introduction}

In Japan, to support children with Severe Motor And Intellectual Disabilities (SMID) and their families, since

\footnotetext{
${ }^{*}$ Corresponding author.
} 
the 1960s, the administration had encouraged these children to be admitted to specialized institutions to provide rearing including whole-body management [1]. However, after the concept of normalization spread following the International Year of Disabled Persons in 1981, the need for "support centered on living at home" has been advocated for those with SMID [2]. Furthermore, in recent years, as a result of changes in medical and welfare policy to shorten hospital stays, there has been a shift wherein more of these children are now based at home from an early age. Of the approximately 40,000 children with SMID in Japan, about 70\% live at home [3]. According to the latest report from the Ministry of Education, approximately 30,000 children with SMID attend special support schools [4]. Although benefits like "they are able to live with their families" and "they do not have to commute to the hospital", are emphasized, complaints such as "we have to wake up in the middle of the night for his/her care", "we cannot go on vacation", and "we cannot pay attention to other siblings" were heard, revealing great mental and physical burdens on household members [5]. In addition, with the Services and Supports for Persons with Disabilities Act implemented in 2006, the use of home services for families with disabled children significantly decreased, and it is reported that the feeling of burden for families, particularly mothers, is rising [6] [7]. In recent years, Japan has been transforming into a society of nuclear families [8], and the same can be said for families that have children with SMID at home. In this environment, what kind of care are nuclear families in Japan giving their children with SMID? What kind of lifestyles are they themselves leading? What does cooperation and role division within families look like?

In Japan, if we don't limit to studies specialized in nuclear families, there are some study reports recently. About "the types of care giving children with SMID in home", it was summarized in the following menu such as "home oxygen therapy" "intratracheal suctioning" "management of gastrostomy tube" and "medication" [1]. About "lifestyles" and "cooperation and role division within families", it was found that there were daily- life issues such as "insufficient service and difficulties in use of services", "care-giver exhaustion", "social isolation", "psychological problems of siblings", and "fear of not being able to continue child rearing" [9]. Mothers, as primary caregiver, make adjustments to a total commitment to SMID child based on their own experimental rule, utilization of local resources, and role expectation from nurses and other mothers [10]. In addition, they also have strong perceptions of role restriction as social pressure of "mothers of SMID child" [10] [11]. Not only mothers but also fathers of SMID child regard spousal existence as a most important family support resource [12]. And the studies about fathers of SMID child have expanded in recent years in Japan, they indicate that actual contents supported by fathers [13] [14] and role perception as a father such as difficulties of managing to work and care [12] [15]. Alternatively, it was reported here that parents of SMID children felt to fulfill social functions and gain confidence from sibling's growth [16]. However, there is no study about the roles and hopes of siblings in homes with a child with SMID.

Therefore, using semi-structured interviews, we extract and describe the roles and hopes of each family member - mother, father, and siblings (children being raised as caregivers and siblings of the child with SMID) in homes with a child with SMID.

\section{Methods}

\subsection{Subject}

Subjects were family members living at home with children with SMID in the suburbs of the Tokyo metropolitan area (primary caregivers, their spouses, and one sibling over age twelve). Subjects were recruited from users of the services of two specialized institutions in Tokyo and three specialized institutions in two prefectures near Tokyo. The subjects were selected on the basis of the following criteria:

- The person is in a stable condition both physically and mentally.

- The person's child or sibling suffers severe motor and intellectual disabilities, has an IQ of 35 or below, and is unable to maintain a standing position.

\subsection{Procedure}

Researchers provided the subjects with a written explanation of the survey content and methods in easily understandable language. Upon obtaining the subjects' consent for participation, researchers traveled to their homes or to private locations designated by the subjects and conducted separate interviews with each family member. The survey period was from September 2013 to August 2014. 


\subsection{Measures}

Lasting for approximately one hour, semi-structured interviews on life with a child with SMID were conducted with each subject, focusing on "one's personal role recognized within the family" and "thoughts about other family members.” Interviews were recorded with the subjects’ approval, using an IC recorder.

\subsection{Ethical Considerations}

While requesting subjects for survey participation, we carefully explained that participation was voluntary, that there would be no disadvantages in not participating, that participation could be stopped at any time, and that their privacy would be protected when researchers presented survey content. We then received consent. This study was conducted with approval from the ethics committees of the researchers' universities.

\section{Results}

\subsection{Overview of Subjects}

We interviewed 25 families rearing children with SMID. Of the 25 families, 17 included siblings of a child with SMID, and for this survey, 11 siblings over age 12 were interviewed. Three siblings were younger than the children with SMID, and eight were older. The average number of people living in the same household, including the child, was 5.2, and six families had grandparents living with them. Of the 25 mothers, 24 were primary caregivers for their children with SMID. One father resigned his employment to become the primary caregiver and dedicate himself to the care of his child with SMID.

The average age of the children with SMID being reared by the subject families was $10.2 \pm 5.5$ years (mean \pm standard deviation). The children's disabilities included cerebral palsy and sequelae of cerebropathy.

The average age of the subject mothers was $41.2 \pm 5.9$ years (mean \pm standard deviation), that of the subject fathers was $42.3 \pm 7.0$ years, and that of the subject siblings was $15.5 \pm 2.3$ years. The average interview length was 65.5 (31 - 88) min for mothers, 49.5 (28 - 80) min for fathers, and 32.7 (16 - 46) min for siblings (mean, range) (Table 1$)$.

\subsection{Family Members' Roles}

Five categories were confirmed for the mothers' personal roles: taking on the main role of providing necessary care to the child with SMID; gathering information about opportunities for the child with SMID to have doctor visits, medical treatments, rehabilitation, and education; making adjustments for the best possible environment for the child with SMID; adjusting the family's life and understanding the state of the whole family, including the spouse and siblings; and trying not to let the future of the sibling(s) be limited.

Mothers took on the majority of the necessary care for children with SMID and gathered information from fellow members of parent groups, medical personnel, and school personnel on opportunities for doctor visits, medical treatments, rehabilitation, and education. While taking responsibility for precise adjustments to the care and treatment environment of the child with SMID, they were also responsible for understanding the state of the whole family, including the spouse and siblings, and adjusting the family's life. They also remained conscious of participating in the sibling's school events, preserving time to spend alone with the sibling, and trying not to let the sibling's daily life and psychological aspect deteriorate or let the sibling's future be limited as a result of having a child with SMID in the family.

The mothers' remarks are in italics below. Parentheses indicate interviewer supplements or author revisions.

The children's short-term residence facilities were only in region $M$ and region $T$, and those are far, so eventually we just thought let's support each other somehow and finance/take care of this as a family. Even though, for the future, it would be ideal to have somewhere close by where we could immediately ask for help if something happened (to either the child or a family member) because Grandma is elderly, and we are also getting on in years. If something happens and we can't watch him, we can put him in (the facility), or if (we put him in) his physical condition worsened, it'd be very difficult, so in preparation, we are thinking that we should start putting him in for short periods of time little by little so he becomes accustomed to it, even though it is far. (ID18).

I am glad for all of the services we are currently receiving. The paper diaper distribution system is very helpful, 
Table 1. Subject overview.

\begin{tabular}{|c|c|c|c|c|}
\hline ID & $\begin{array}{l}\text { Age of } \\
\text { SMID child }\end{array}$ & Diagnoses & Family members & Social services in use/schools \\
\hline 1 & 14 & Acute encephalopathy & 2 adults and 3 siblings & $\begin{array}{l}\text { - } \quad \text { Preschool } \\
\text { - } \quad \text { Childcare support temporarily used for siblings } \\
\text { - Special-needs school }\end{array}$ \\
\hline 2 & 7 & $\begin{array}{l}\text { Periventricular } \\
\text { leukomalacia, epilepsy } \\
\text { (WEST syndrome) }\end{array}$ & 2 adults & $\begin{array}{l}\text { - } \quad \text { Chat meetings in rehabilitation room } \\
\text { - Hospital visits: } 10 \text { days a month } \\
\text { - Home care assistance: once a week }\end{array}$ \\
\hline 3 & 14 & $\begin{array}{l}\text { Periventricular } \\
\text { leukomalacia }\end{array}$ & 4 adults and 2 siblings & $\begin{array}{l}\text { - } \quad \text { Special-needs school: } 5 \text { days a week } \\
\text { - } \quad \text { OT and PT: } 1 \text { - } 2 \text { times a month } \\
\text { children } \rightarrow \text { Kindergarten }\end{array}$ \\
\hline 4 & 7 & Hypoxic encephalopathy & 2 adults and 3 siblings & $\begin{array}{l}\text { - Home-visit education: once a week } \\
\text { - Home-visit nursing: once a week, home-visit } \\
\text { bathing: twice a week, rehabilitation: once a } \\
\text { week } \\
\text { - Inspection of respirator and home-visits by a } \\
\text { doctor: every fortnight } \\
\text { - Respite care: once every } 3 \text { months (for } 1 \text { week) }\end{array}$ \\
\hline 5 & 10 & Syringomyelia (atypical) & 3 adults and 3 siblings & $\begin{array}{l}\text { - Home-visit nursing/bathing, home visits by a } \\
\text { doctor } \\
\text { - Home-visit education: } 3 \text { times a week } \\
\text { Respite care: once every } 3 \text { months (6 nights } \\
\text { and } 7 \text { days) } \\
\text { - Home care assistance: (used up to } 6 \text { hours per } \\
\text { time, } 2 \text { - } 3 \text { times a month) }\end{array}$ \\
\hline 6 & 16 & $\begin{array}{l}\text { Influenza-associated } \\
\text { encephalopathy }\end{array}$ & 5 adults and 2 siblings & $\begin{array}{l}\text { - Rehabilitation (PT): once a month } \\
\text { - School: Monday-Friday, After-school } \\
\text { childcare: } 2 \text { days a week } \\
\text { - Home care assistance, home-visit bathing, } \\
\text { - family support services }\end{array}$ \\
\hline 7 & 5 & $\begin{array}{l}\text { New influenza-associated } \\
\text { encephalopathy }\end{array}$ & 2 adults and a sibling & $\begin{array}{l}\text { - } \quad \text { Respite care: once every } 3 \text { months (for } 6 \text { days) } \\
\text { - Home-visits by a doctor: once a month } \\
\text { - Home care assistance: once a week, } \\
\text { rehabilitation, home-visit nursing/bathing }\end{array}$ \\
\hline 8 & 7 & Cerebral palsy & 2 adults and a sibling & $\begin{array}{l}\text { - Home-visits by a doctor: once a months, ST } \\
\text { - Free school: } 5 \text { days a week } \\
\text { - OT, PT: once a month }\end{array}$ \\
\hline 9 & 12 & $\begin{array}{l}\text { Fukuyama-type congenital } \\
\text { muscular dystrophy }\end{array}$ & 2 adults and a sibling & $\begin{array}{l}\text { - } \quad \text { Special-needs school: weekdays } \\
\text { - } \quad \text { Vome care assistance: } 3 \text { times a week } \\
\text { - } \quad \text { rehiting a doctor: once every } 3 \text { months, } \\
\text { - Respite care at a medical welfare facility }\end{array}$ \\
\hline
\end{tabular}




\section{Continued}

10

7

Procollagen 4A1 gene abnormality

11

4

Pallister Killian syndrome, chronic respiratory disease

12 5 induced by CMV infection

Periventricular leukomalacia, cerebral palsy, epilepsia nutans

Functional disorder of cerebral palsy

Diffuse axonal injury, ersistent disturbance of consciousness
2 adults and a sibling

2 adults and 2 siblings

2 adults and 2 siblings

$$
2 \text { aduls and a sibling }
$$$$
\text { to }
$$

4 adults and 2 siblings

3 adults and 2 siblings

2 adults and a sibling

5 adults and a sibling

4 adults and a sibling

4 adults and 2 siblings
2 adults and a sibling
- Special-needs school: weekdays

- Home-visit nursing (bathing): once a week

- Short stay: undetermined schedule

- After-school day-care service: twice a week

- PT: once a month

- Day-care center: 5 times a week

- Home-visit nursing: once a week

- Day-care service: twice a week

- Visiting a doctor: once a month, PT: once a week

- Short stay: 1 or 2 times a year

- Special-needs school: weekdays (dropped off and picked up by mother)

- Short stay (rarely used), day-care service

- Home care assistance/bathing: twice a week, PT: twice a month

- Home-visit nursing (bathing and tracheostomy management): once a week

- Visiting a doctor: once every 2 weeks

- Home-visit nursing: 4 times a week (once of them is OT)

- Home-visit education: twice a week

- Dental visits: once every 2 weeks

- $\quad$ ST (sole proprietorship): once every 2 weeks

- Special-needs school: weekdays

- Home-visit nursing: once a month

- Special-needs school: weekdays (with mother standing by)

- Home-visit bathing: 3 times a week, rehabilitation: once a week

- Visiting a doctor: once a month, Baclofen therapy: once every 3 months, Dentistry

- Short stay: once a year

- Day-care service: several days a week

- PT: twice a month, OT: once every 3 months

- Hospitalization for rehabilitation: once a year

- $\quad$ Special-needs school: weekdays

- Home care assistance (bathing): 3 times a week

- Rehabilitation: once a month (for Dohsa-Hou)

- Temporary support services during daytime: weekdays

- Rehabilitation: once a month 


\begin{tabular}{|c|c|c|c|c|}
\hline \multicolumn{5}{|c|}{ Continued } \\
\hline 21 & 6 & $\begin{array}{l}\text { Cerebral palsy, } \\
\text { leukomalacia }\end{array}$ & 3 adults and a sibling & $\begin{array}{l}\text { - PT at the municipal rehabilitation center: once } \\
\text { a month } \\
\text { - PT: once every } 2 \text { months }\end{array}$ \\
\hline 22 & 8 & Acute encephalopathy & 2 adults and 2 siblings & $\begin{array}{l}\text { - } \text { Special-needs school: weekdays } \\
\text { - } \quad \text { Rehabilitation: once a month } \\
\text { - Visiting a doctor: } 1 \text { or } 2 \text { times a month } \\
\text { - } \quad \text { Short stay }\end{array}$ \\
\hline 23 & 18 & Chromosomal abnormality & 2 adults & $\begin{array}{l}\text { - Special-needs school: weekdays (with mother } \\
\text { standing by, free access to the classroom) } \\
\text { - Temporary support services during daytime: } \\
\text { once a week } \\
\text { - Home care assistance (bathing): twice a week, } \\
\text { home-visit bathing: once a week }\end{array}$ \\
\hline 24 & 4 & $\begin{array}{l}\text { Pallister Killian syndrome, } \\
\text { atrial septal defect }\end{array}$ & 2 adults and a sibling & $\begin{array}{l}\text { - Day-care service: once a week } \\
\text { - Home-visit rehabilitation: once a week, } \\
\text { home-visit nursing: twice a week }\end{array}$ \\
\hline 25 & 3 & $\begin{array}{l}\text { Hydrocephalus, } \\
\text { symptomatic epilepsy, } \\
\text { mental retardation, } \\
\text { functional disorder of trunk }\end{array}$ & 2 adults and a sibling & $\begin{array}{ll}\text { - } & \text { PT } \\
\text { - } & \text { Visiting a doctor } \\
\text { - } & \text { Kindergarten (from April), day-care service: } \\
& \text { once a week }\end{array}$ \\
\hline
\end{tabular}

OT: occupational therapy, PT: physical therapy, ST: speech therapist, CMV: cytomegalovirus.

and I looked for and found a bathing service not only during the day but also at night, and that is also very helpful. And even though it is set at 5 o'clock, they are flexible, so I can say, "Next week we have some plans, so let's make it 6 o'clock." (ID19)

Of course, I try to make time to spend just with my daughter [younger sister of the child with SMID]. She has weekly practice, so during those times, I drop her older brother off at the facility, and that's when we talk with just the two of us or go shopping together. (ID8)

Seven categories of fathers' confirmed roles were given: division of roles with the mother for housework and (the child's) home care; work adjustments; counseling the mother; coordination of family vacations; relationships with service providers; negotiations with government agencies; and legal (court) negotiations.

Most fathers were taking care of the child before work, after work, and on days off; in other words, any time that did not interfere with their work. They also discussed the child's medical treatment and care policies with the mother. There were also fathers who planned family vacations to coordinate with the child's short-term facility stays to release family stress.

In some cases, fathers negotiated for nursery school and kindergarten enrollment and for public subsidies for services, such as visiting bathing services and home care equipment like wheelchairs and inhalers. They made appeals about their families' predicament and elicited responses from the government. In one case, a child suffered permanent injury from a car accident, and the father fought in court for compensation to support the child's future care.

I change the first diaper after [he] wakes up, and before going to work, I do the urethral catheterization and injection. When I get home from work, I start the injection between nine-thirty and ten o'clock, and that takes a little under two hours. Then I give [him] his medicine and change [his] diaper [After that it's bedtime.]. My wife isn't as physically strong as I am, so I try to get him to bed as early as possible. She works hard during the day because I am away at work. I try to do what I can while I am at home. (ID7)

It's a little unfair to A [child's name], but every year we four other family members go on vacation when we have $A$ in the facility. In the past, it has generally been beach vacations. We try to go once a year. If we didn't take vacations without $A, I$ think the other family members would all fall apart. (ID12) 
Five categories of siblings' confirmed roles were given: help caring for the child, be a normal sibling, do not cause trouble for parents, support the mother, and take on future care of the child with SMID.

Differences were found in content and degree of siblings' narratives; however, they all had the experience of helping care for the child from a very young age. Specifically, there was a wide range of care, from watching the child by his/her bedside to very difficult care, such as assistance with meals, moving the child, and replacing suctions and cannulas. These were spoken of as "natural because I am the sibling" and "the same as a regular sibling would do" to help care for the child.

The siblings often observed and understood that their parents, particularly the mother, were busy taking care of the child with SMID. For example, when the physical condition of the child with SMID was poor and the parents were busy preparing to go to the hospital, the siblings were mindful of trying not to talk too much, preparing their own meals, and trying not to cause trouble for the parents. They recognized their role as supporting the mother, confirmed by two thoughts: wanting to reduce the mother's current burden and helping when the mother, due to old age, will be unable to care for the child with SMID.

They believed that it would be their responsibility to care for the child with SMID in the future, and there were siblings who believed they would take on the care of the child with SMID when they became adults. There were also siblings who thought they wanted to become doctors specializing in treating children with SMID.

I have helped with meal assistance and moving the child since I was very young. In our family, basically, whoever is free will get [the child] out of bed, change the diaper, set him/her in the wheelchair and feed him/her. That's been our policy since the beginning. (ID6)

When my parents are busy taking care of my sibling... I try to not talk much and not cause any trouble. (ID1, ID6)

In the future, when my mother's body has grown old and stiff, I think I will have to do all of the home care for the child with SMID, so it will be easier for me if I learn a certain level [of care procedures] now, rather than starting then. (ID20)

I would like to work together with my two younger brothers to continue taking care of my older brother. That's why I've thought since I was small that I would like to become a doctor. (ID1)

On the descriptive section, parents clearly and concretely wrote about various concerns, anxieties, and needs for support. Their descriptions were placed into subcategories (Table 2).

We divided descriptions of their concerns into 5 subcategories; SMID child's symptoms, parents' work, facilities, social activity, and siblings. One primary caregiver wrote the following about her child's symptoms, "I'm concerned that new symptoms might emerge as she grows and develops. Last year, she had a kidney stone and bloody urine for over 6 months. There was nothing that eased my concern about this problem".

We divided parents' descriptions of their anxieties into 5 subcategories; SMID child's life, insufficient support, finances, parents' health, and siblings. Many parents had similar comments about their children's life, such as, "I have anxiety about her life after she graduates from the special school" and "I can't imagine the future after she graduates from the special school".

We found 7 subcategories related to the need for support; support in facilities, visiting services, coordination, support to allow caregivers to pursue personal goals, advising, support for siblings, and financial support. Most parents wrote about the need for support in facilities, such as, "I hope that there is a facility that can provide hospitable care for my child", "I need a service that can provide care for my child after school and during long school vacations", and "I want facilities that provide convenient respite care services".

Siblings wrote less than their parents because they did not perform as much of the care for the SMID child as their parents did. But one sibling, who was 14 years old, wrote about his anxieties, "I have to choose my career with one point in mind, and that's to be able to continue caring for her (the SMID child)". Another boy, 12 years old, wrote, "After my parents die, I'm worried about whether or not we (siblings) can take care of him (the SMID child)" (Table 3).

\subsection{Thoughts about Other Family Members}

Mothers hoped that their spouses, the fathers, would assume as much responsibility for care as they could. However, when the father's time was greatly constricted due to a busy work schedule, the mothers experienced some situations in which they felt asking for the father's help was unavoidable, particularly for difficult, fixed 
Table 2. The role of each family member living with a child with SMID and expectations of other family members.

\begin{tabular}{|c|c|c|c|}
\hline & Mother & Father & Sibling(s) \\
\hline 1. Role & $\begin{array}{l}\text { - Providing care as the primary } \\
\text { caregiver of the child with SMID } \\
\text { - Coordinating the home care } \\
\text { environment } \\
\text { - Collecting information regarding } \\
\text { the opportunities for child's } \\
\text { consultations, nursing, } \\
\text { rehabilitation and education } \\
\text { - Understanding and coordinating } \\
\text { the state of the whole family } \\
\text { - Making arrangements to reduce } \\
\text { limits on siblings in their daily } \\
\text { lives and future path (ensuring } \\
\text { some time to refresh and spending } \\
\text { time alone with the siblings) }\end{array}$ & $\begin{array}{l}\text { - Sharing the role of mother in } \\
\text { care and household duties } \\
\text { - Coordination between family } \\
\text { task and job } \\
\text { - } \quad \text { Being a mentor for mother } \\
\text { - Coordinating family leisure, } \\
\text { such as a trip } \\
\text { - Involving himself with service } \\
\text { representatives } \\
\text { - Negotiating with } \\
\text { - } \text { administrative bodies }\end{array}$ & $\begin{array}{l}\text { - Helping with looking after the } \\
\text { child with SMID } \\
\text { - } \quad \text { Trying to be an ordinary } \\
\text { sibling } \\
\text { - Trying not to cause the } \\
\text { parents trouble } \\
\text { - Supporting mother } \\
\text { - Taking responsibility for } \\
\text { future care of the child with } \\
\text { SMID }\end{array}$ \\
\hline $\begin{array}{l}\text { 2. Expectations } \\
\text { of other family } \\
\text { members }\end{array}$ & $\begin{array}{l}\text { - Wanting father to take charge of } \\
\text { the child's care as much as } \\
\text { possible } \\
\text { - Appreciating sibling(s) if they help } \\
\text { care and household duties without } \\
\text { much burden (Not wanting to limit } \\
\text { future options of the sibling(s) or } \\
\text { place a care burden on them) } \\
\text { - Wanting sibling(s) to adequately } \\
\text { participate in school or enrichment } \\
\text { lessons, and hoping to their } \\
\text { fulfilling daily lives }\end{array}$ & $\begin{array}{l}\text { - Wanting mother to work with } \\
\text { when providing care for the } \\
\text { child } \\
\text { - Wanting sibling(s) to become } \\
\text { partners working with when } \\
\text { providing care for the child } \\
\text { - Wanting sibling(s) to have } \\
\text { their own lives }\end{array}$ & $\begin{array}{l}\text { - Wanting mother to have some } \\
\text { time for rest } \\
\text { - Wanting father to support the } \\
\text { whole family } \\
\text { Wanting father to arrange the } \\
\text { traffic line of daily life in the } \\
\text { house (required for caring for } \\
\text { the child with SMID) } \\
\text { - Wanting grandparents to be } \\
\text { nearby } \\
\text { - Wanting grandparents to } \\
\text { communicate with the child } \\
\text { with SMID (touching or } \\
\text { talking) } \\
\text { - Wanting grandmother to do } \\
\text { household duties (to reduce } \\
\text { mother's duties) } \\
\text { Wanting other sibling(s) to } \\
\text { look after the child with } \\
\text { SMID }\end{array}$ \\
\hline
\end{tabular}

occasions such as doctor's visits for the child with SMID and the siblings' school events.

For the siblings, on the other hand, there were cases in which mothers did not want the other children to perform home care, cases in which they thought it would be nice if they took on some care responsibilities if they had free time and if they wanted to, and cases in which they wanted them to take on as much care responsibility as they could. Regardless, all mothers felt that sufficiently participating in school and lessons and leading a fulfilling daily life were priorities. They did not want the existence of the child with SMID to limit the siblings' future choices or to cause an excessive burden of care.

Father usually wakes up early and goes to bed late, so he most often comes home after [the family] has gone to bed. But visits to the treatment center are very difficult, so he goes with me then. Those times, and when our older or younger [siblings] have big events, we feel very sad, so he takes time off work. Those are the only times that must be flexible. [Do you, the mother, primarily do the entire home care for the child?] Yes, mostly. (ID12)

I don't think of making the siblings perform home care. Although when my husband retires, I'd like him to do more. (ID18)

The child does need medical care, but usually I just ask his/her older sister to watch him/her for just a moment. Then I do shopping nearby. The older sister can do the suction and take out the feeding tube when it's finished. I consider it lucky when she's home, so I do ask her. (ID15)

On holidays, when the older sister is home, she will do as much of the home care for the child as possible. I ask her very naturally, and I always think that I should not be the only one who can do the home care. It would be a problem if something happened to me, and there was no one to step in. (ID20) 
Table 3. Temporal support needs as a family member living with a child with SMID.

\begin{tabular}{|c|c|c|c|}
\hline & In the early stage of home care & Currently & In the future \\
\hline Mother & $\begin{array}{l}\text { Willing to have suggestions from } \\
\text { experts about how to proceed home } \\
\text { care, especially how to judge the } \\
\text { physical state of the child }\end{array}$ & $\begin{array}{l}\text { Willing to have referrals to } \\
\text { social resources appropriate to } \\
\text { whole family as well as the } \\
\text { child with SMID, such as job } \\
\text { assistance for mother, and } \\
\text { actually use those supports }\end{array}$ & $\begin{array}{l}\text { Hoping to have a facility with } \\
\text { medical care available for } \\
\text { accommodating the child with } \\
\text { SMID after graduating from high } \\
\text { school. Also willing to have an } \\
\text { effective arrangement of social } \\
\text { services in preparation for a case } \\
\text { the parents aging and no longer be } \\
\text { able to care for the child with } \\
\text { SMID, rather than taking the care } \\
\text { over to other family members. }\end{array}$ \\
\hline Father & $\begin{array}{l}\text { Willing to have more simplified } \\
\text { administrative procedures, such as } \\
\text { applications for support. Willing to } \\
\text { obtain practical information from } \\
\text { family association etc. regarding } \\
\text { facilities or services for respite care } \\
\text { or day care. Also willing to obtain } \\
\text { information on support systems } \\
\text { outside of the current community. }\end{array}$ & $\begin{array}{l}\text { Hoping for a barrier-free town, } \\
\text { and improved user-friendliness } \\
\text { of public transport and places } \\
\text { for disabled individuals. }\end{array}$ & $\begin{array}{l}\text { - Expecting expansion of } \\
\text { available services such as day } \\
\text { services, respite, and } \\
\text { transportation support }\end{array}$ \\
\hline Sibling & & $\begin{array}{l}\text { - Hoping for enhanced home } \\
\text { care assistance caring for the } \\
\text { child with SMID at home, the } \\
\text { acquisition of and the reliable } \\
\text { implementation of medical } \\
\text { care skills by school welfare } \\
\text { workers, and reliable support } \\
\text { by external assistants in case } \\
\text { of acute deterioration of the } \\
\text { child. }\end{array}$ & $\begin{array}{l}\text { - Hoping to improvement of } \\
\text { institutions that accept children } \\
\text { with SMID after graduating from } \\
\text { special-needs school, and external } \\
\text { public supports in case that } \\
\text { developmental care becomes } \\
\text { difficult at home. }\end{array}$ \\
\hline
\end{tabular}

While the fathers understood that the mothers' care practices for the child were the center of the care, they believed that they could not place all care responsibilities on the mother and that they themselves had to support the mother.

Although in some cases, the father considered the sibling to be another family member involved in the child's care, there were also cases in which the father believed the parents should take all responsibility for the care of the child with SMID because the siblings' had their own lives.

Mother pushes herself so hard, and she's a hard worker. She doesn't have time to relax. So, I do think I have to follow. (ID8)

I think the younger sisters will be able to do a lot of the care once they enter elementary school. For now, under the watch of a parent, we are training them how to do some care, such as suction and other exchanges. (ID4)

I tell the sibling everything about the process of having a disabled child. But I do not want him/her to take part in the caring process because it will crush his/her life. The parents [will do] the nursing care. I would like to find a system so that the sibling will not have to do all the work in the future. (ID17)

While siblings were busy with daily care for the child with SMID, they were also grateful to their mothers for the care the mothers gave their sibling. The siblings spoke of their fathers as being important persons in supporting the entire family. Additionally, when the child with SMID's physical condition was poor and the child had to be hospitalized, the siblings said they were extremely thankful for their grandparents or relatives who were by their side in place of their mother. They considered their grandparents and relatives' presence an important part of their own healthy life, growth, and development.

In cases with extended families, grandparents became daily playmates to the child with SMID and were in charge of household chores, such as preparing meals. Siblings recognized this as being connected to support for their mother. 
Most siblings objectively understood each family member's role, and while they were grateful to each, they also understood the need for support from external resources.

I have nothing but gratitude for Mother, who not only takes care of my younger [disabled] brother but also takes care of everything, housework, everything to do with the house/family, and even my college things. (ID20)

When my mother has to be at the hospital all day with my [disabled] sibling, and I am lonely, my grandmother comes over and cooks and does the laundry for me. It's really great. There have been countless times like that, but somehow we overcome them and are here now. My grandmother has a very significant presence in my life. (ID18)

When a home-helper is here to care for our severely disabled child, my mother and grandmother have more free time. I'd like it if we could have more of those people. (ID21) (Figure 1)

\section{Discussion}

As primary caregivers for children with SMID, mothers were responsible for adjusting the child with SMID's care and home treatment environment while also adjusting the entire family's lifestyle. Specifically, after understanding and considering the social situations of the other family members, spouses, and siblings, they expected other family members to take on individual roles within the family, including care for the child with SMID. Therefore, there was no significant difference between the mothers' expectations for other family members' roles and the actual situations. This can be seen as the mothers' assuming primary responsibility for care of the child while also taking on the role of empowering the whole family. Although the disabilities differed, previous research has reported several times on mothers' role of empowering the family [17] [18]. Also similar to findings in previous research [19], mothers looked to the future and thought that it would be difficult to continue home treatment with just their or their family's strength alone, so for respite, many of them tried to integrate caregivers into their family's life from the time the child was small. Nurses (home-visit and hospital nurses) must assess not only the mothers' support needs, the child's current home treatment environment, and the family's care system but also consider a long-term view and provide information and support coordination for the future.

While staying engaged in their work, fathers also performed care for the child on behalf of the mother for the short time they were home and sometimes also functioned as a counselor for the mother. As representatives of the family, they also fulfilled a wide range of roles including planning recreational activities, such as family vacations to refresh family members and reduce stress, negotiating current content and systems of service with specialists, and appearing as the family's representative contact in government and legal proceedings. Similar to mothers, fathers not only wanted practical services and information to support the child's home treatment lifestyle but also took into consideration a care system that focused on the whole family's future, including that of siblings. Thus, we can say that fathers comprehensively support the whole family economically, psychologically, and socially. Nurses (home-visit and hospital nurses) should take the father's existence seriously and build a positive relationship not only with the mother but also with the father who "supports" the whole family, and the nurses should function as supporters who empower the entire family [20].

Siblings objectively understand each family member's relationship with the child with SMID, recognize each role, and take on the role for themselves of supporting family members. Although many of the subjects had thoughts such as "I want Mother to rest [from the care of the child]" and "I can't cause trouble", none said that they had any personal troubles or difficulties in their daily lives. Many subjects spoke of their prospects for the future with the child with SMID, and several spoke of the need for current and future public support; we assumed that the siblings intended to be active rather than passive in leading a life with the child with SMID. Interview studies with siblings have been very rare till date, and we can consider this study to have obtained useful information. Regarding nurses' (home-visit and hospital nurses) support for siblings, it is important to accept their actual feelings in real time, as well as move toward introducing both tangible and intangible public support and adjust the family's internal and external support balance so that siblings' participation in and burden of care does not become excessive in the long term.

This study included many cases in which relationships within the family were going well, and not only the mother but also the father and siblings actively assumed part of the responsibility of caring for the child with SMID. However, since there are also cases of single parents and cases in which siblings are not at all involved in the care of the child with SMID, it is also important to build and make adjustments to a support system that allows 


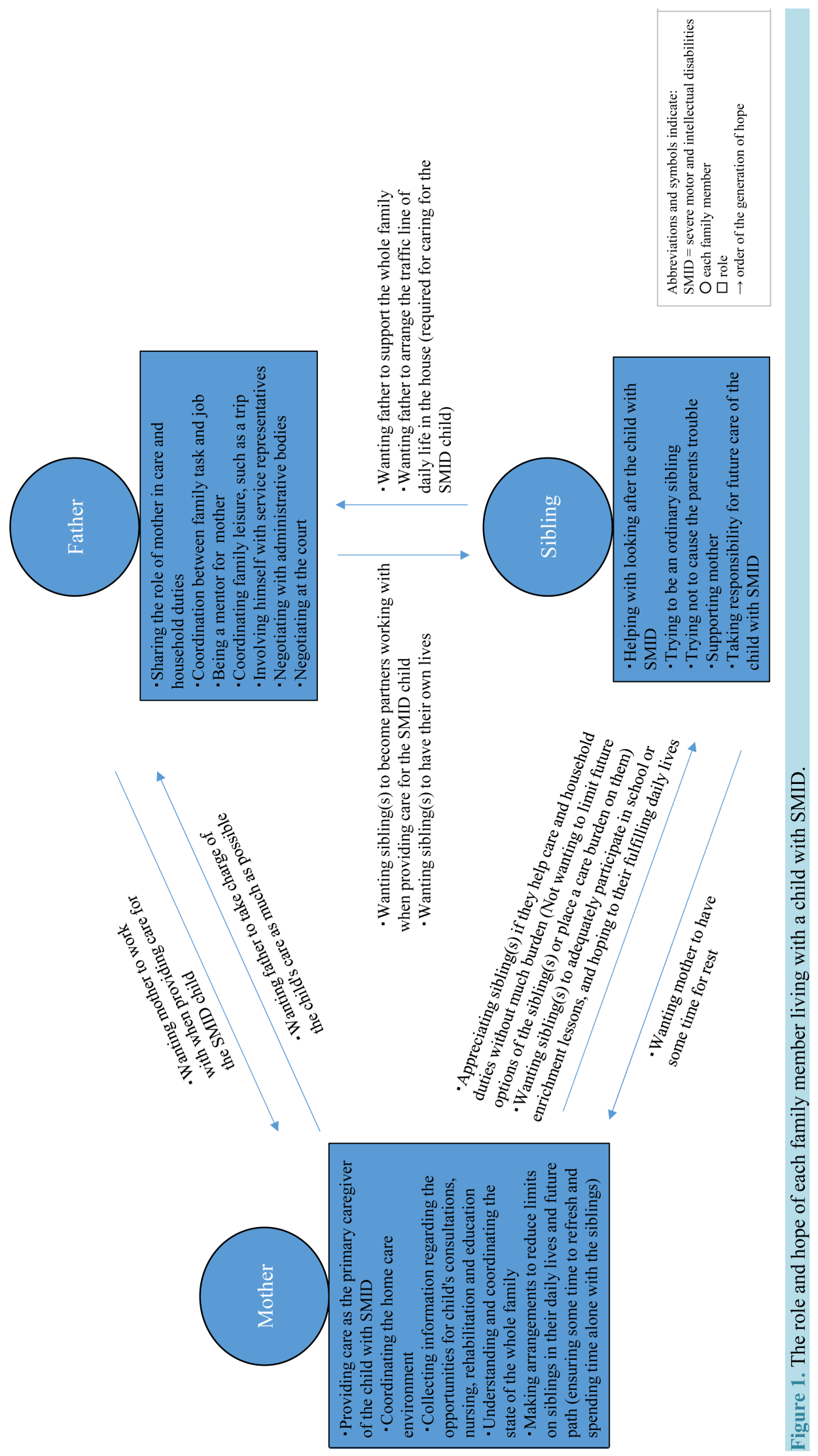


the child with SMID and the family to lead a stable life. Specific ways in which nurses should support families are the following: 1) assess family roles and thoughts and look not only at the child's home treatment environment and the family's current care system but also provide information and support coordination for the future from a long-term perspective (particularly if there are siblings, introduce public support early and proceed with adjustments, so the siblings' participation in and burden of care does not become excessive). 2) Empower the family and develop positive relationships with fathers who comprehensively support the entire family economically, psychologically, and socially.

\section{Conclusion}

Mothers' personal roles were divided in five such as mainly providing care to their child with SMID, adjusting and understanding family members' lifestyle living together. They seemed to get along well about empowering the whole family. Fathers had seven roles such as cooperating with mothers about care of their child with SMID, negotiation with outside of family. They committed their time for taking care of their child except during work. There were five roles of siblings such as helping care of a child with SMID, taking on roles of care in the future. All siblings had experienced helping care of child with SMID from a very early age, though there was a wide range of care. Through rearing a child with SMID, each family member had personal roles and expectations for others and those interrelated and maintained their life. Nurses should assess nuclear families in multifaceted ways, considering not only primary caregiver's but also other family members' roles, the relationships among family members, degree of connection between the family unit and local community, and the family's resource utilization.

\section{Acknowledgements}

This study received a Grant-in-Aid for Challenging Exploratory Research supported by the Ministry of Education, Culture, Sports, Science and Technology, Japan (2015-2017), and Pfizer Health Research Foundation (2015-2016) (Principal investigator: Rie WAKIMIZU).

\section{Disclosure}

The authors declare that they have no competing interests.

\section{References}

[1] Ezoe, T. (2006) The Concept and Definition of Severe Motor and Intellectual Disabilities. In Asakura, T., Ed., Total Care of the Child with Severe Motor and Intellectual Disabilities, Herusu Shuppan, Tokyo, 4-6. (In Japanese)

[2] Hori, T. (2006) Lobbying Movements by Parents of Children with Severe Motor and Intellectual Disabilities during High Economic Growth and Their Background. Japanese Journal of Social Welfare, 47, 31-44.

[3] Okada, K. (2001) The History of Severe Motor and Intellectual Disabilities. Journal of Pediatric Nursing, 24, 10821089. (In Japanese)

[4] Ministry of Education, Culture, Sports, Science and Technology (MEXT) (2015) Special School in Japan Today. http://www.mext.go.jp/a_menu/shotou/tokubetu/002.htm

[5] Wakimizu, R. and Fujioka, H. (2011) Changes in Family’s Anxiety and Needs Rearing Children with Severe Motor and Intellectual Disabilities in the Light of the Family Empowerment Process. Journal of Severe Motor and Intellectual Disabilities, 36, 147-155. (In Japanese)

[6] Matsuzawa, A., Tamiya, N., Kashiwagi, M., Tanaka, R., Takeya, T. and Nomura, Y. (2013) Changes of Burden Feelings on Mothers with Challenges Children Caused by the Introduction of "Service and Support for Persons with Disabilities Act” and Related Factors thereof. The Journal of Child Health, 72, 54-64. (In Japanese)

[7] Ushio, R. (2014) Study on Quality of Life of Parents who Rear a Child with Severe Motor and Intellectual Disabilities at Home. Journal of Severe Motor and Intellectual Disabilities, 39, 441-446. (In Japanese)

[8] Suzuki, K. and Watanabe, K. (2014) Family Nursing. 4th Edition, Japanese Nursing Association Publishing Company, Tokyo, 36. (In Japanese)

[9] Fujioka, H., Wakimizu, R., Yamaguchi, K., Sato, N., Nishigaki, K. and Numaguchi, C. (2014) The Actual Situation of Families Rearing Children with Severe Motor and Intellectual Disabilities at Home: A Literature Review. The Journal of Child Health, 73, 599-607. (In Japanese) 
[10] Ishii, Y. and Nakagawa, K. (2013) Caregiving without Sacrificing Oneself: Perceptions of Caregiving among Mothers of Children with Severe Motor and Intellectual Disabilities Based on Their Narratives. The Japanese Journal of Health and Medical Sociology, 24, 11-20.

[11] Sugimoto, A., Nakamura, Y., Umeda, H., Akahane, E., Naijo, E. and Shibutani, H. (2009) The Features of Family Functions of Families who Have a Child with Disabilities Living in Certain Prefecture. Journal of Japan Academy of human Care Science, 2, 49-56.

[12] Murakami, Y. (2012) Research on the Difference of the Recognition to the Child of a Father and a Mother with a Handicapped Child. International Nursing Care Research, 11, 1-11.

[13] Shimono, J., Endo, Y. and Takeda, J. (2013) An Adjustment Process at Home of Fathers of Children with Severe Motor and Intellectual Disabilities to Lead to the Performance of Father's Roles. Journal of Japanese Society of Children Health Nursing, 22, 1-8.

[14] Tanaka, M. (2008) Experience of the Father who Finds Power of Child Care from Child with Severe Motor and Intellectural Disabilities. Jichi Medical University Journal of Nursing, 5, 15-23.

[15] Hirano, M. (2004) Change of Perception and Behavior on Fathers of Children with Cerebral Palsy. Journal of Japanese Society of Child Health Nursing, 13, 18-23.

[16] Tanigawa, R. and Nakamura, Y. (2009) The Relationship of Belief and Acceptance of Disability of Families who Have a Child with Disabilities $1^{\text {st }}$ Report: Focusing on a Process of Acceptance of Disability. The Collected Papers of Japanese Nursing Association. Child Nursing, 39, 257-259.

[17] Koren, P.E., DeChillo, N. and Friesen, B.J. (1992) Measuring Empowerment in Families whose Children Have Emotional Disabilities: A Brief Questionnaire. Rehabilitation Psychology, 37, 305-321. http://dx.doi.org/10.1037/h0079106

[18] Wakimizu, R., Fujioka, H. and Yoneyama, A. (2010) Empowerment Process for Families Rearing Children with Developmental Disorders in Japan. Nursing and Health Sciences, 12, 322-328. http://dx.doi.org/10.1111/j.1442-2018.2010.00533.x

[19] Nishigaki, K., Kuroki, H., Fujioka, H. and Kamibeppu, K. (2014) Relevant Factors of Primary Caregiver’s Demands of Respite Care for Severely Disabled Children at Home. The Journal of Child Health, 73, 475-483. (In Japanese)

[20] Fujioka, H., Wakimizu, R., Okubo, Y. and Yoneyama, A. (2014) Empowerment of Families Rearing Children with Severe Motor and Intellectual Disabilities at Home. Medical and Health Science Research, 5, 41-53.

\section{List of Abbreviations}

Severe Motor and Intellectual Disabilities (SMID) 